\title{
ECONOMIC CHARACTERISTICS OF GRAPE PRODUCTION IN SOUTH BANAT ${ }^{1}$
}

\author{
Dragan Milič́2, Danica Glavaš-Trbič ${ }^{3}$, Mirela Tomaš-Simin ${ }^{4}$, Dejan Jankovič ${ }^{5}$, \\ Vladislav Zekić ${ }^{6}$
}

\section{Summary}

Wine production in Serbia has a long tradition. Serbia has great potentials for the production of grape and wine, but they are at a low level of utilization. Grape production in Serbia takes place on only 25,000 ha with an average annual production of 285,571 t of grapes with variations according to year. The vineyards and wine production are in a significant decline, while the main bearers of production are small family householdes or individual producers. The research presented in this paper is the economic characteristics of grapes production in the region of South Banat, Vršac wine-growing region, which occupies $81.2 \%$ of the total vineyard area in this part of AP Vojvodina.

Key words: grape production, vine, viticulture, economic characteristics, the Republic of Serbia.

1 Paper is part of the research within the III 46006 - Sustainable agriculture and rural development in the function of accomplishing strategic goals of the Republic of Serbia in the Danube Region and ON 179028 -Rural labour market and the rural economy in Serbia - diversification of income and poverty reduction, financed by the Ministry of Education, Science and Technological Development of Republic of Serbia. Project period 2011-2016.

2 Dragan Milić Ph.D., Assistant Professor, University of Novi Sad, Faculty of Agriculture, Trg Dositeja Obradovića no. 8, 21000 Novi Sad, Serbia, Phone: +381 63 560135, E-mail: dragan.milic@polj.edu.rs

3 Danica Glavaš - Trbić M.Sc., Assistant, University of Novi Sad, Faculty of Agriculture, Trg Dositeja Obradovića no. 8, 21000 Novi Sad, Serbia, Phone: +381 63 8878701, E-mail: danicagt@polj.uns.ac.rs

4 Mirela Tomaš-Simin M.Sc., Assistant, University of Novi Sad, Faculty of Agriculture, Trg Dositeja Obradovića no. 8, 21000 Novi Sad, Serbia, Phone: +38162 240123, E-mail: mirelat@polj.uns.ac.rs

5 Dejan Janković Ph.D., Assistant Professor, University of Novi Sad, Faculty of Agriculture, Trg Dositeja Obradovića no. 8, 21000 Novi Sad, Serbia, Phone: +381 63 574750, E-mail: jankovic@polj.uns.ac.rs Correspondent Author.

6 Vladislav Zekić Ph.D., Full Professor, University of Novi Sad, Faculty of Agriculture, Trg Dositeja Obradovića no. 8, 21000 Novi Sad, Serbia, Phone: +381 63 560214, E-mail: zekic@polj.uns.ac.rs 
JEL: $Q 12, Q 13$

\section{Introduction}

Agricultural production is a very complex process that largely depends on natural conditions, requires planning and decision making that affects the success of the production. To make timely and correct decisions is closely linked with the possession of appropriate knowledge and skills, information, and discusses the proper spotting potential problems and finding appropriate and timely solutions in order to maximize revenue while reducing costs, which is the basic objective of any production. Agricultural production is characterized by certain specific features which make it different from other forms of production and that must be taken into account in the economic evaluation, because they have a significant impact on the achieved production and economic results in agricultural production.

Perennials are significant for certain categories of agricultural areas. Such crops represent intensive production enabling the engagement of more people and allowing generation of more revenue per unit area compared to most crops have a higher degree of processing, and also have a high economic and socio-economic importance.

Usually grape production and wine production is one organizational unit. As wine production has spread worldwide, methods of production have become more diverse and we have seen increasing complexity and inter-connectedness of winemaking enterprises, spanning a full range from small household-based producers to large global beverage corporations (Overton et al., 2016). Grapes are a high quality product with significant nutritional and therapeutic value. Grape is one of the oldest cultivated fruit species. There are more products made from grapes, but wine is the most common. As a globally recognized beverage wine was deeply incorporated in the tradition of many nations, and the manner of its consumption often reflects the culture, traditions and lifestyles of local communities. In addition to the health benefits, wine often carries a sign of prestige, especially for wealthy consumers, and to its spending the most influence has traditions, religions and habits, and living standard of consumers (Vlahović et al., 2012).

Grape production is very widespread in the world, especially in Europe (Petrović et al., 2015). At the world wine market is dominated by three countries, France, Italy and Spain, which together account for half of the total world production (FAO, 2014). In addition to these three European countries from global grape producers are China, the US and Chile. The world's largest exporters of wine are France, Italy, Spain, Australia and Chile, while the biggest importers are UK, USA, Germany, Belgium, Canada and Japan. Up to the end of the 1980s, "Old World" countries, and particularly France and Italy, dominated the international wine market. Since the beginning of the 1990s, their supremacy has been challenged by new international players, who are recording spectacular performance in terms of both exported volumes and values (Cusmano et al., 2010). The traditional wine producing countries are experiencing a decrease in their domestic consumption and non-producing countries are slowly opening their markets to wine and developing their domestic consumption. In this hyper-competitive and fragmented environment, all actors try to capitalize on the growing 
demand for wine in the 12 to 15 most important developing markets (Remaud et al., 2006). Developing markets, such as Australia and China, are becoming increasingly significant, but are often catered for by highly marketed New World wines, particularly by national producers in the above cases (Pike, et al., 2006). The world wine market is the subject of increasing interest to Californian, Australian and other New World wine producers as their national outputs grow and they become more export oriented (Wittwer et al., 2003). On the other hand, the demand for wine has also registered a geographical change with a fall in the traditional market, in line with social changes that have occurred through time, and an increase in new consumer markets (Crescimanoo et al., 2014). Trade in wines is increasingly becoming more two-ways, thus more of an intra-industry type providing differentiation of wines for consumers and encouraging specializations and market segmentations by producers. The increasing preference in the world wine trade is directed to wine qualities (Ivanović et al., 2005). Winemaking is a traditional branch of agriculture in Serbia (Petrović et al., 2015). Also, in the last fifty years, world tourism included an offer related to viticulture and winemaking, which proved to be very successful. Wine became the motive to discover new destinations, visit well known and esteemed wine cellars, the search for new producers, exploring other cuisines, customs, habits and events (Pivac et al., 2009). Wine production in Serbia has a tradition of over two millennia (Vlahović et al., 2012). Serbia has great potentials for the production of grapes and wine, but they are at a low level of utilization. Therefore, today in Serbia the vineyards and wine production herself are in a significant decline. The main pillars of production are a small family householdes or individual producers who are in a lot of unfavorable economic situation. Particular negative influence has age structure. It is estimated that more than half of the vineyards are over thirty years old. Also, the unfavorable effect have unresolved issues of lending in order to restore the vineyards, unfavorable assortment, high production costs, inadequate prices of grapes and wine, market conditions, etc. One of the important steps in solving the current situation is increase the interest the state, vineprocessors and wine producers for creation of viticulture and wine production association with the aim to ensure the integrity of viticulture, wine production, development and research, market development, the control of grapes and wine export, trade and distribution of wine and to fulfill the requests and rules of the EU (Hambalkova, 2006). Competitive vine-grower associations and cooperatives ensure moderately acceptable price levels, whereas without family or smallholder labour, vine cultivation would be unprofitable (Di Vita et al., 2013). Although the current economic situation in our country does not provide security in primary agricultural production, investment in the planting of vineyards provides significant economic effects (Sredojević et al., 2015).

\section{Materials and methods}

The object of research presented in this paper is economic characteristics of vine or grapes production on individual farm in Gudurica not far from Vršac which owns the winery "Nedin". 
This holding in Gudurica for its production and results ${ }^{7}$ is representative farm in Vršac vineyards. Vršac vineyards lead with their wine production in South Banat area. The main goal of the research is to determine the economic results of grape production and financial results per product in South Banat area, based on the analysis of representative households. Method for calculating the results of production, amount and structure of costs of production of grapes which was used is the analytical accounting calculations of production reduced per area unit (Marko et al., 1998). Elements of analytical calculations are production value and production cost, on the basis of which is expressed profit and profitability of production.

The research includes evaluating the economic effects in the production of grapes at the individual farm in the vineyards of Vršac in economic 2012, 2013 and 2014 year. Data on individual producers of grapes in Vršac area are the result of research in the field as well as the Census in 2012, while analyzing the situation and changes of wine production in Serbia and abroad was conducted on the basis of official data and publications of the Republic Institute of Statistics and FAO statistics.

\section{Grape production in Serbia}

Serbia has very favorable conditions for grape growing, production and consumption of grape. Favourable climatic conditions and geographical position of Serbia are the main comparative advantage in the production and placement of wine (Petrović et al., 2015). Despite favorable conditions, it is not at a satisfactory development level and lagging behind countries with similar production characteristics. Areas under vineyards in Serbia as well as wine production were significantly decreased. Individual producers are in a rather unfavorable position. The main limiting factors for grape production in Serbia are very old plants, which should be renewed and for this they need a large financial investments. It is estimated that more than half of the vineyards are older then 30 years. Another reason for the decline is that family farms are beareres of wine production, while big agricultural enterprises are significantly smaller manufacturers. Small plots prevent the use of productive machines and performing the necessary agrotechnical measures. Also, outdated varieties make it difficult to offer a better standard and quality that is required for the market.

In Serbia, of the total quantity of grapes produced per year up to $85 \%$ is processed into wine, and the rest is used for fresh consumption. According to latest data from Census in 2012 the area under vineyard in Serbia occupies about 25,000 ha. In the total production of grapes in Europe Serbia participates with two percent, respectively, is in $12^{\text {th }}$ place after production.

During the period of 2011 - 2014, the average grape production was 285,571 t per year with

7 Based on the research that was conducted within the project "Socio-economic characteristics, territorial and economic the factors that influence the success in the business of small private wineries in the APV", Faculty of Agriculture in Novi Sad, funded by the Provincial Secretariat for Agriculture, Water and Forestry AP Vojvodina, it was found that the production results of this farm are approximately equal to the production results of other farms in this region. For this reasons it is selected for the analysis and presentation of economic characteristics of grape production in South Banat. 
variations from 324,919 $\mathrm{t}$ in year 2011 to 233,239 in year 2014, as shown in Table 1 . These data show that production of grape has a constant decrease in this period.

Table 1. Grapes production in Serbia for the period 2011 - 2014. year

\begin{tabular}{|c|c|c|c|}
\hline Year & $\begin{array}{c}\text { Production } \\
(\mathbf{t})\end{array}$ & Number of vine (millions) & $\begin{array}{c}\text { Yield per vine } \\
\text { (kg) }\end{array}$ \\
\hline 2011 & 324,919 & 274 & 1.19 \\
\hline 2012 & 263,419 & 267 & 1 \\
\hline 2013 & 320,491 & 244 & 1.31 \\
\hline 2014 & 233,239 & 222 & 1.05 \\
\hline Average & $\mathbf{2 8 5 , 5 7 1}$ & $\mathbf{2 5 2}$ & $\mathbf{1 . 1 4}$ \\
\hline
\end{tabular}

Source: Statistical Office of the Republic of Serbia

In addition, it is experienced a decrease in the number of vines from 274 million in 2011 to 222 million of vines in 2014. The yield of grapes per native vine also varies from year to year, mostly depending on weather conditions, which greatly affect the yield. On average for the researched period yield per vine amounted $14.1 \mathrm{~kg}$. The total wine production in the period 2011-2014 year ranged from 158,084,500 liters in 2011 to 198,183,000 liters in 2014 (RIS, 2015).

South Banat region is located in the southeastern part of AP Vojvodina region on the western slopes of the mountains of Vrsšc and in the area of Deliblatska Sands. In this part of Vojvodina are located Vršac vineyards, Belocrkvansko vineyards and vineyard of Deliblatska Sands. The South Banat region has a total of 1,730.69 hectares of vineyards, of which under the Vršac vineyards is $1,405.48$ hectares of vineyards, which makes $81.2 \%$ of the whole area. In this region 786 households owns a vineyard with average area of vineyards within a farm of 2.2 hectares. This reon is known for its wines winery "Vršac Vineyards", but lately more by wines from Gudurice and Deliblatska Sands. In Vršac vineyards are mostly represented white grape varieties for the production of quality wines. The most common variety is the Italian Riesling with over $50 \%$ of the total production in this region.

\section{Basic data on the researched farm}

Nedin family farm in Gudurica for its production and placement is representative farm in the field of grape and wine producers in the region of South Banat, or Vršac wine-growing region, which occupies $81.2 \%$ of the total vineyard area in this part of AP Vojvodina. Family Nedin work with viticulture since 1993, a winery called "Family winery Nedin" is opened since 2009. The family owns 3 hectares of vineyards and their grapes are processed into wine. The vineyards are represented Italian and Rhine Riesling, Traminac, White Burgundy and red varieties of Cabernet Sauvignon and a little less of Merlot, but they also produce wine with the same name and blend called White Baptism with which this winery won significant awards along which is the most important gold medal at the international Temerin wine fair. For now the red varieties produces only $10-15 \%$ of total wine production. The capacity of this winery is around 15,000 liters annually, which varies depending on the natural production conditions in certain years. The negative impact of natural disasters was offset by the vineyards up to 
three different strokes. This concept of diversification in viticulture is known from before, because it was used in this region benefit from the German population in past centuries. In this way, can be avoided a significant capital investment in protection of weather disasters, which amounts per hectare about 13,000 euros. The winery has the wine tasting room which was built in 2012, with a capacity of about 80 guests. Winery visit both domestic and foreign tourists. The aim of this producer is to expand to 7-8 hectares, which would mean to double the current production. Planned production is 20,000 liters of wine. The wines from the winery Nedin in $70 \%$ of cases are sold on the doorstep, and the rest at selected restaurants in Vršac, Belgrade and Pančevo.

\section{Economic characteristics of grape production}

\section{Investments in vineyards}

Investments in forming of one hectare of vineyards and building a winery is the sum of all investments incurred during their construction to commissioning as a fixed asset. The costs of raising 1 ha include all activities for the first four years, as well as costs of material and they may significantly differ from country to country, depending on the type of soil, terrain and required for irrigation (FAO, 2009). Also, the amount of investments depend on a range of other factors such as the condition of the terrain, the type of the object, the length of the investment period, the dynamics and the distribution of investments by years, etc. According to FAO data, the cost of raising 1 ha of vineyards, including all necessary operations in the first four years, differ significantly from country to country, in European countries range from 20,000 to 25,000 euros (FAO, 2009). Viticulture represents a highly intensive production, which requires large investments in labor and capital per unit. Below is showed an example of the structure and the amount of total investment in raising one hectare of vineyard analized through the period of three years.

Table 2. Total investments in raising of one hectare of vineyards

\begin{tabular}{|c|c|c|c|c|c|c|c|c|}
\hline \multirow{2}{*}{ No } & \multirow{2}{*}{ Elements } & \multirow{2}{*}{ Unit } & \multicolumn{3}{|c|}{ Year } & \multirow{2}{*}{ Total } & \multirow{2}{*}{$\begin{array}{c}\text { Price } \\
\text { (dinars) }\end{array}$} & \multirow{2}{*}{$\begin{array}{l}\text { Amount } \\
\text { (dinars) }\end{array}$} \\
\hline & & & I & II & III & & & \\
\hline 1 & $\begin{array}{l}\text { Purchase of } \\
\text { land }\end{array}$ & ha & 1 & & & 1 & $300,000.00$ & $300,000.00$ \\
\hline 2 & \begin{tabular}{|l|}
$\begin{array}{l}\text { Soil } \\
\text { preparation }\end{array}$ \\
\end{tabular} & & & & & & & \\
\hline 2.1 . & Manure & $\mathrm{kg}$ & 15,000 & & & 15,000 & 2.7 & $40,500.00$ \\
\hline 2.2 . & Deep plowing & ha & 1 & & & 1 & $30,000.00$ & $30,000.00$ \\
\hline 2.3 . & Leveling & ha & 1 & & & 1 & $5,000.00$ & $5,000.00$ \\
\hline 3 & $\begin{array}{l}\text { Planning and } \\
\text { measuring }\end{array}$ & ha & 1 & & & 1 & $10,000.00$ & $10,000.00$ \\
\hline 4 & Seedlings & kom & 5,000 & & & 5,000 & 60.00 & $300,000.00$ \\
\hline 5 & Planting & ha & 1 & & & 1 & $20,000.00$ & $20,000.00$ \\
\hline 6 & $\begin{array}{l}\text { Regular } \\
\text { maintenance in } \\
\text { I year }\end{array}$ & & & & & & & \\
\hline
\end{tabular}




\begin{tabular}{|c|c|c|c|c|c|c|c|c|}
\hline \multirow{2}{*}{ No } & \multirow{2}{*}{ Elements } & \multirow{2}{*}{ Unit } & \multicolumn{3}{|c|}{ Year } & \multirow{2}{*}{ Total } & \multirow{2}{*}{$\begin{array}{c}\text { Price } \\
\text { (dinars) }\end{array}$} & \multirow{2}{*}{$\begin{array}{l}\text { Amount } \\
\text { (dinars) }\end{array}$} \\
\hline & & & I & II & III & & & \\
\hline 6.1. & Hilling & ha & 1 & & & 1 & $20,000.00$ & $20,000.00$ \\
\hline 6.2. & $\begin{array}{l}\text { Inter-row } \\
\text { cultivation }\end{array}$ & ha & 1 & & & 1 & $20,000.00$ & $20,000.00$ \\
\hline 6.3. & Protection & ha & 1 & & & 1 & $10,000.00$ & $10,000.00$ \\
\hline 7 & $\begin{array}{l}\text { Setting up } \\
\text { poles and } \\
\text { wires }\end{array}$ & & & & & & & \\
\hline 7.1. & Poles & kom & & 500 & & 500 & 600.00 & $300,000.00$ \\
\hline 7.2 . & Wire & $\mathrm{kg}$ & & 1,100 & & 1,100 & 140.00 & $154,000.00$ \\
\hline 7.3. & Restraints & kom & & 5,000 & & 5,000 & 30.00 & $150,000.00$ \\
\hline 8 & $\begin{array}{l}\text { Regular } \\
\text { maintenance in } \\
\text { II year }\end{array}$ & & & & & & & \\
\hline 8.1 . & Protection & ha & & 1 & & 1 & $40,000.00$ & $40,000.00$ \\
\hline 8.2 & Fertilization & $\mathrm{kg}$ & & 300 & & 300 & 40.00 & $12,000.00$ \\
\hline 9 & $\begin{array}{l}\text { Pruning } \\
\text { and Regular } \\
\text { maintenance in } \\
\text { III year }\end{array}$ & & & & & & & \\
\hline 9.1 . & Pruning & ha & & & 1 & 1 & $25,000.00$ & $25,000.00$ \\
\hline 9.2. & Forming & ha & & & 1 & 1 & $5,000.00$ & $5,000.00$ \\
\hline 9.3 . & Digging $3 x$ & ha & & & 1 & 1 & $25,000.00$ & $25,000.00$ \\
\hline 9.4. & Binding & ha & & & 1 & 1 & $5,000.00$ & $5,000.00$ \\
\hline 9.5 . & Protection & ha & & & 1 & 1 & $85,000.00$ & $85,000.00$ \\
\hline 9.6. & $\begin{array}{l}\text { Inter-row } \\
\text { cultivation }\end{array}$ & ha & & & 1 & 1 & $20,000.00$ & $20,000.00$ \\
\hline & TOTAL & & & & & & & $1,756,500.00$ \\
\hline
\end{tabular}

Source: Authors' calculation based on own research

Total investment in 1 hectare vineyard amounts 1,756,500.00 dinars, or 5,269,500.00 dinars for 3 hectares of vineyards.

\section{The volume of production}

In general, in the vineyard production level of realized yield depends primarily on the following factors: natural conditions, substrate selection, cultivation form, varieties, agrotechnics practices and other factors. The change of the yield, sugar content and acidity of the verjuice depends largely on the year in which production took place, and to a lesser extent from the tested version of the treatment. According to FAO studies, depending on the variety of grape, planting density and plan of agrotechnical measures a yield of 5 to 20 tons of grapes per hectare could be achieved (FAO, 2009).

On average at the examined farm for the period 2012 - 2014 was achieved stable yield, which amounted to an average of $7,167 \mathrm{~kg} / \mathrm{ha}$, which is detailed showed in Table 3 . 
Higher yield than the average was achieved in 2013 and amounted to 8,000 kg/ha.

Table 3. Yield of grapes in the period 2012 - 2014. year

\begin{tabular}{|c|c|c|c|}
\hline Year & Area (ha) & Yield (kg/ha) & Total production (kg) \\
\hline 2012 & 3 & 7,000 & 21,000 \\
\hline 2013 & 3 & 8,000 & 24,000 \\
\hline 2014 & 3 & 6,500 & 19,500 \\
\hline Average & $\mathbf{3}$ & $\mathbf{7 , 1 6 7}$ & $\mathbf{2 1 , 5 0 0}$ \\
\hline
\end{tabular}

Source: Authors' calculation based on own research

\section{Production value}

The production value of grapes is calculated as the product of the yield per unit area and the selling price per unit of product. The production value is proportional to the amount of yield as well as the selling price, ie, their increase leads to an increase in the total value of production and vice versa.

Table 4. Actual value of grape production in the period 2012 - 2014. year

\begin{tabular}{|c|c|c|c|}
\hline Year & Yield (kg/ha) & $\begin{array}{c}\text { Average purchase prices } \\
\text { of grapes (din/kg) }\end{array}$ & Production value (din/ha) \\
\hline 2012 & 7,000 & 68.63 & $480,410.00$ \\
\hline 2013 & 8,000 & 51.12 & $408,960.00$ \\
\hline 2014 & 6,500 & 79.88 & $519,220.00$ \\
\hline Average & $\mathbf{7 , 1 6 7}$ & $\mathbf{6 6 . 5 4}$ & $\mathbf{4 6 9 , 5 3 0 . 0 0}$ \\
\hline
\end{tabular}

Source: Authors' calculation based on own research

In the research period 2012 - 2014 year at an average yield of 7,167 kg/ha and average selling price (source Republican Institute of Statistics) of $66.54 \mathrm{din} / \mathrm{kg}$ it was achieved average annual production value of 469,530 dinars/ha, which is shown in more detailes in the previous table.

\section{Costs of production}

In wine growing, as in many branches of agriculture, the capacity to contain production costs represents an indispensable choice for the enterprise. Lowering mean costs allows a business to arrive to market with a lower price (albeit above mean cost) than the competition, who are destined to lose market shares to the competitor able to produce at more convenient costs (Sgroi et al., 2014). In terms of the broader theoretical significance the costs represent value term of consumption of material resources and labor which are transformed through the production process into new products and services (Milić, 2015). Production costs expressed as a monetary value of capital equipment, labor and objects of labor spent in one production in agriculture as well as in vineyard production are high when they are expressed per unit of capacity. Fixed assets last for many years and therefore have a specificity to gradually technically and economically expended, or to gradually their value transferred to the product, which is in the structure of production costs expressed as amortization. In the following calculations, ie calculation of grape production, each year is burdened with a certain amount of amortization that is obtained based on the average lifetime of vineyards of 40 years. For 
the facilities amount of amortization is calculated based on the average lifetime of 50 years.

The financial result was obtained as the difference between the value of production and costs for each year observed per area unit. Grape is profitable product as it is evidenced by the profit per area unit.

Table 5 shows the calculation of the cost of production of one hectare of grapes in 2012 year.

Table 5. Calculation of grape production per hectare in 2012

\begin{tabular}{|c|c|c|c|c|c|}
\hline \multicolumn{6}{|c|}{ CALCULATION OF PRODUCTION PER HECTARE } \\
\hline No. & Elements & Unit & Quantity & Price & Value \\
\hline 1 & 2 & 3 & 4 & 5 & 6 \\
\hline 1. & PRODUCTION VALUE & $\operatorname{din} / \mathrm{ha}$ & & & $480,410.00$ \\
\hline 1.1. & Main product & $\mathrm{kg} / \mathrm{ha}$ & $7,000.00$ & 68.63 & $480,410.00$ \\
\hline 1.2. & By-product and other income & $\mathrm{kg} / \mathrm{ha}$ & & & \\
\hline 2. & PRODUCTION COSTS & din/ha & & & $352,253.00$ \\
\hline 2.1 & Material costs & $\operatorname{din} / \mathbf{h a}$ & & & $136,840.00$ \\
\hline 2.1.1. & Fertilizer 8:16:24 & $\mathrm{kg} / \mathrm{ha}$ & 250.00 & 40.00 & $10,000.00$ \\
\hline 2.1 .2 . & Plant protection & din/ha & & & $111,840.00$ \\
\hline 2.1.3. & Other material costs & $\operatorname{din} / \mathrm{ha}$ & & & $15,000.00$ \\
\hline 2.2. & Work operation on plant & $\operatorname{din} / \mathrm{ha}$ & & & $61,000.00$ \\
\hline 2.3. & Immaterial costs & din/ha & & & $4,500.00$ \\
\hline 2.3.1. & Water contribution & din/ha & 1.00 & $1,500.00$ & $1,500.00$ \\
\hline 2.3 .2 . & Other intangibles & din/ha & 1.00 & $3,000.00$ & $3,000.00$ \\
\hline 2.4. & Costs of fixed assets & $\operatorname{din} / \mathrm{ha}$ & & & $43,913.00$ \\
\hline 2.5. & Gross wages & $\operatorname{din} / \mathrm{ha}$ & & & $100,000.00$ \\
\hline 2.6. & General expenses of farm & din/ha & & & $6,000.00$ \\
\hline 3. & PROFIT & $\operatorname{din} / \mathrm{ha}$ & & & $128,157.00$ \\
\hline 4. & LOSS & $\operatorname{din} / \mathrm{ha}$ & & & \\
\hline
\end{tabular}

Source: Authors' calculation based on own research

Wine growing is labor and capital intensive branch of agricultural production, and requires a significant investment of funds. The preceding table shows that the value of production of grapes for 2012 was $480,410.00 \mathrm{din} / \mathrm{ha}$, the cost of production were 352,253.00 din/ha and calculated profit was $128,157.00$ dinars/ha. Of the total costs material costs were highest (136,840.00 din/ha). When analyzing material costs used NPK 8:16:24 fertilizer amounted for $10,000.00 \mathrm{din} / \mathrm{ha}$, costs of plant protection (herbicides, insecticides and fungicides) were also high - 111,840.00 din/ha and other operating expenses amounted to 15,000.00 din/ha. Gross wages were calculated to $100,000.00 \mathrm{din} /$ ha due to high labor requirements. Share/ strucutre of costs is shown in Table 6 and Graph 1. 
Table 6. Structure of costs in grape production in 2012

\begin{tabular}{|c|l|r|r|}
\hline No & DESCRIPTION OF COSTS & VALUE (din/ha) & SHARE (\%) \\
\hline 1. & Material costs & $136,840.00$ & 38.85 \\
\hline 2. & Costs of services & $61,000.00$ & 17.32 \\
\hline 3. & Immaterial costs & $4,500.00$ & 1.28 \\
\hline 4. & Gross personal income & $100,000.00$ & 28.39 \\
\hline 5. & Overheads & $6,000.00$ & 1.70 \\
\hline 6. & $\begin{array}{l}\text { Costs of fixed assets - amortization } \\
\text { and maintennance }\end{array}$ & $43,913.00$ & 12.47 \\
\hline & TOTAL & $\mathbf{3 5 2 , 2 5 3 . 0 0}$ & $\mathbf{1 0 0}$ \\
\hline
\end{tabular}

Source: Authors' calculation based on own research

The share of certain costs in the production of grapes in 2012 is shown in Graph 1.

Graph 1. Structure of costs in grape production in 2012

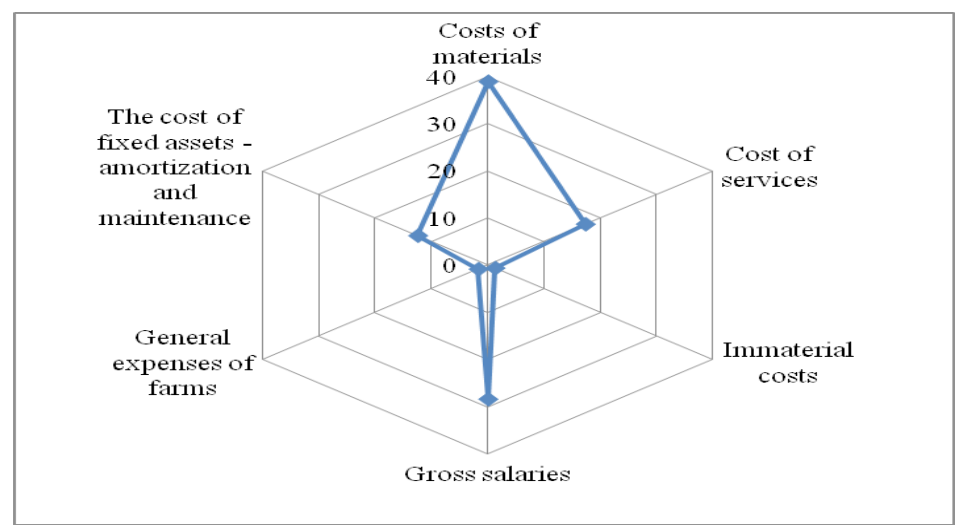

Source: Authors' calculation based on own research

From the previous table and chart one can see that material costs have the largest share in total costs accounting for $38.85 \%$. Also cost of seasonal workers wages are important and account for $28.39 \%$ of total costs, followed by the cost of services with $17.32 \%$ and cost of fixed assets with $12.47 \%$. The smallest shares are accounted by immaterial costs and overheads with $1.28 \%$ and $1.70 \%$ respectively.

The following table shows the calculation of the cost of producing one hectare of grapes in 2013.

Table 7. Calculation of grape production per hectare in 2013

\begin{tabular}{|l|l|c|c|c|c|}
\hline \multicolumn{7}{|c|}{ CALCULATION OF PRODUCTION PER HECTARE } \\
\hline No. & Elements & Unit & Quantity & Price & Value \\
\hline 1 & 2 & 3 & 4 & 5 & 6 \\
\hline $\mathbf{1 .}$ & PRODUCTION VALUE & din/ha & & & $\mathbf{4 0 8 , 9 6 0 . 0 0}$ \\
\hline 1.1. & Main product & $\mathrm{kg} / \mathrm{ha}$ & $8,000.00$ & 51.12 & $408,960.00$ \\
\hline
\end{tabular}




\begin{tabular}{|c|c|c|c|c|c|}
\hline \multicolumn{6}{|c|}{ CALCULATION OF PRODUCTION PER HECTARE } \\
\hline No. & Elements & Unit & Quantity & Price & Value \\
\hline 1.2. & By-product and other income & $\mathrm{kg} / \mathrm{ha}$ & & & \\
\hline 2. & PRODUCTION COSTS & din/ha & & & $304,828.00$ \\
\hline 2.1 & Material costs & din/ha & & & $87,415.00$ \\
\hline 2.1.1. & Fertilizer 8:16:24 & $\mathrm{kg} / \mathrm{ha}$ & 250.00 & 43.00 & $10,750.00$ \\
\hline 2.1.2. & Plant protection & $\operatorname{din} / \mathrm{ha}$ & & & $61,665.00$ \\
\hline 2.1.3. & Other material costs & $\operatorname{din} /$ ha & & & $15,000.00$ \\
\hline 2.2. & Work operation on plant & din/ha & & & $63,000.00$ \\
\hline 2.3. & Immaterial costs & $\operatorname{din} / \mathbf{h a}$ & & & $4,500.00$ \\
\hline 2.3 .1 . & Water contribution & din/ha & 1.00 & $1,500.00$ & $1,500.00$ \\
\hline 2.3.2. & Other intangibles & $\operatorname{din} /$ ha & 1.00 & $3,000.00$ & $3,000.00$ \\
\hline 2.4. & Costs of fixed assets & din/ha & & & $43,913.00$ \\
\hline 2.5 . & Gross wages & din/ha & & & $100,000.00$ \\
\hline 2.6 . & General expenses of farm & din/ha & & & $6,000.00$ \\
\hline 3. & PROFIT & $\operatorname{din} / \mathrm{ha}$ & & & $104,132.00$ \\
\hline 4. & LOSS & $\operatorname{din} / \mathrm{ha}$ & & & \\
\hline
\end{tabular}

Source: Authors' calculation based on own research

The value of grape production in 2013 (table 7) was 408,960.00 din/ha and total production costs were $304,828.00 \mathrm{din} / \mathrm{ha}$, which means that the total profit in 2013 was $104,132.00 \mathrm{din} / \mathrm{ha}$. As in the previous year the highest expenses are the expenses for salaries amounting to $100,000.00 \mathrm{din} / \mathrm{ha}$ and the total material costs that were calculated at 87,415.00 din/ha. Costs of used NPK 8:16:24 fertilizer amounts 10,750.00 din/ha and the cost of herbicides used 1,375.00 din/ha, insecticides 2,200.00 din/ha and fungicide $58,090.00 \mathrm{din} / \mathrm{ha}$, respectively. Total costs of plant protection in 2013 amounted to $61,665.00 \mathrm{din} / \mathrm{ha}$. The following table presents the percentage and absolute share of certain costs in total costs of grape production in 2013.

Table 8. Structure of costs in grape production in 2013

\begin{tabular}{|c|l|r|r|}
\hline No & DESCRIPTION OF COSTS & VALUE (din/ha) & SHARE (\%) \\
\hline 1. & Material costs & $87,415.00$ & 28.68 \\
\hline 2. & Costs of services & $63,000.00$ & 20.67 \\
\hline 3. & Immaterial costs & $4,500.00$ & 1.48 \\
\hline 4. & Gross personal income & $100,000.00$ & 32.81 \\
\hline 5. & Overheads & $6,000.00$ & 1.97 \\
\hline 6. & $\begin{array}{l}\text { Costs of fixed assets - amortization } \\
\text { and maintennance }\end{array}$ & $43,913.00$ & 14.41 \\
\hline & TOTAL & $\mathbf{3 0 4 , 8 2 8 . 0 0}$ & $\mathbf{1 0 0}$ \\
\hline
\end{tabular}

Source: Authors' calculation based on own research

The share of certain costs is presented in graph 2 . 
Graph 2. Structure of costs in grape production in 2013

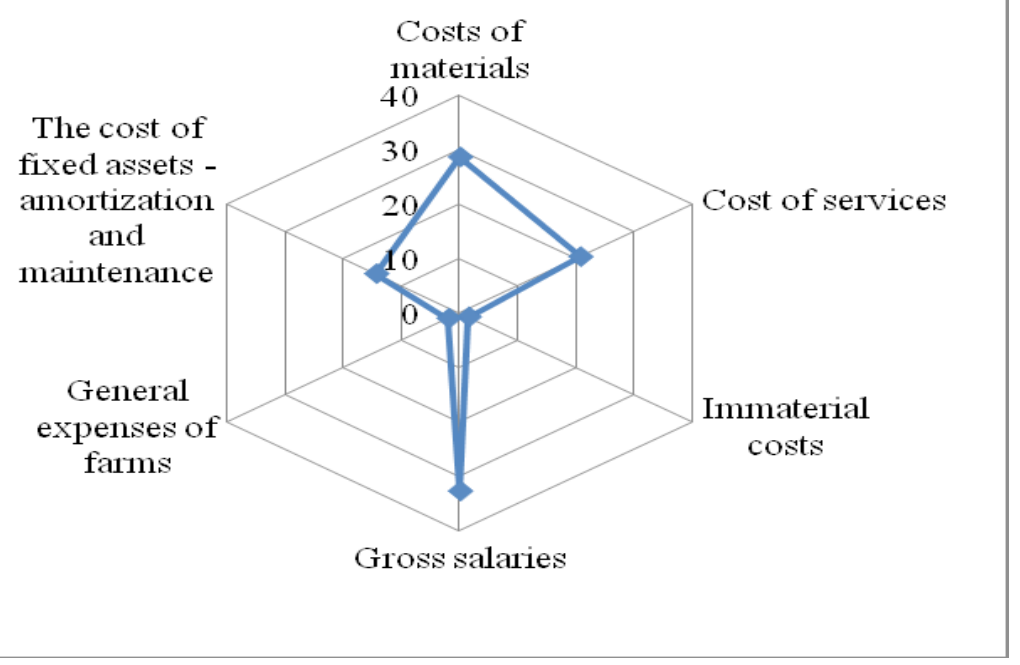

Source: Authors' calculation based on own research

When analyzing the share of certain costs in the overall cost structure in 2013, it was found that the gross wages of seasonal workers dominate with $32.81 \%$ as a result of important engagement of labor, especially in matters of pruning and harvesting. Material costs were high with a share of $28.68 \%$, followed by the cost of services with a share of $20.67 \%$, the cost of fixed assets $14.41 \%$, overheads with $1.97 \%$, and intangible costs with $1.48 \%$.

Table 9. Calculation of grape production per hectare in 2014

\begin{tabular}{|c|c|c|c|c|c|}
\hline \multicolumn{6}{|c|}{ CALCULATION OF PRODUCTION PER HECTARE } \\
\hline No. & Elements & Unit & Quantity & Price & Value \\
\hline 1 & 2 & 3 & 4 & 5 & 6 \\
\hline 1. & PRODUCTION VALUE & din/ha & & & $519,220.00$ \\
\hline 1.1. & Main product & $\mathrm{kg} / \mathrm{ha}$ & $6,500.00$ & 79.88 & $519,220.00$ \\
\hline 1.2. & By-product and other income & $\mathrm{kg} / \mathrm{ha}$ & & & \\
\hline 2. & PRODUCTION COSTS & din/ha & & & $334,178.00$ \\
\hline 2.1 & Material costs & din/ha & & & $116,265.00$ \\
\hline 2.1.1. & Fertilizer 8:16:24 & $\mathrm{kg} / \mathrm{ha}$ & 250.00 & 40.00 & $10,000.00$ \\
\hline 2.1.2. & Plant protection & $\mathrm{din} / \mathrm{ha}$ & & & $91,265.00$ \\
\hline 2.1.3. & Other material costs & $\mathrm{din} / \mathrm{ha}$ & & & $15,000.00$ \\
\hline 2.2 . & Work operation on plant & din/ha & & & $63,500.00$ \\
\hline 2.3. & Immaterial costs & $\mathrm{din} / \mathrm{ha}$ & & & $4,500.00$ \\
\hline 2.3.1. & Water contribution & $\operatorname{din} /$ ha & 1.00 & $1,500.00$ & $1,500.00$ \\
\hline
\end{tabular}




\section{CALCULATION OF PRODUCTION PER HECTARE}

\begin{tabular}{|l|l|c|c|c|r|}
\hline No. & \multicolumn{1}{|c|}{ Elements } & Unit & Quantity & \multicolumn{1}{c|}{ Price } & \multicolumn{1}{c|}{ Value } \\
\hline 2.3 .2$. & Other intangibles & $\operatorname{din} /$ ha & 1.00 & $3,000.00$ & $3,000.00$ \\
\hline 2.4. & Costs of fixed assets & $\operatorname{din} / \mathbf{h a}$ & & & $\mathbf{4 3 , 9 1 3 . 0 0}$ \\
\hline $\mathbf{2 . 5 .}$ & Gross wages & $\operatorname{din} / \mathbf{h a}$ & & & $\mathbf{1 0 0 , 0 0 0 . 0 0}$ \\
\hline $\mathbf{2 . 6 .}$ & General expenses of farm & $\operatorname{din} / \mathbf{h a}$ & & & $\mathbf{6 , 0 0 0 . 0 0}$ \\
\hline 3. & PROFIT & $\operatorname{din} / \mathbf{h a}$ & & & $\mathbf{1 8 5 , 0 4 2 . 0 0}$ \\
\hline 4. & LOSS & $\operatorname{din} / \mathbf{h a}$ & & & \\
\hline
\end{tabular}

Source: Authors' calculation based on own research

Calculations of grape production for 2014(table 9) shows the value of production at 519,220.00 $\mathrm{din} / \mathrm{ha}$, which was an expression of the high selling prices of grapes in $2014(79.88 \mathrm{din} / \mathrm{kg})$. Total production costs were 334,178.00 din/ha and the profit was 185,042.00 din/ha. In 2014 material costs dominated in total production costs $(116,265.00 \mathrm{din} / \mathrm{ha})-10,000.00 \mathrm{din} / \mathrm{ha}$ for NPK 8:16:24 fertilizer, 91,265.00 din/ha for herbicides, insecticides and fungicides. The cost of wages were 100,000.00 din/ha. The following table presents the percentage and absolute share of certain costs in total costs of grape production in 2014.

Table 10. Structure of costs in grape production in 2014

\begin{tabular}{|c|l|r|r|}
\hline No & DESCRIPTION OF COSTS & VALUE (din/ha) & SHARE (\%) \\
\hline 1. & Material costs & $116,265.00$ & 34.79 \\
\hline 2. & Costs of services & $63,500.00$ & 19.00 \\
\hline 3. & Immaterial costs & $4,500.00$ & 1.35 \\
\hline 4. & Gross personal income & $100,000.00$ & 29.92 \\
\hline 5. & Overheads & $6,000.00$ & 1.80 \\
\hline 6. & $\begin{array}{l}\text { Costs of fixed assets }- \text { amortization } \\
\text { and maintennance }\end{array}$ & $43,913.00$ & 13.14 \\
\hline & TOTAL & $\mathbf{3 3 4 , 1 7 8 . 0 0}$ & $\mathbf{1 0 0}$ \\
\hline
\end{tabular}

Source: Authors' calculation based on own research

The share of certain costs in the production of grapes in 2013 is shown in Graph 3. 
Graph 3. Structure of costs in grape production in 2014

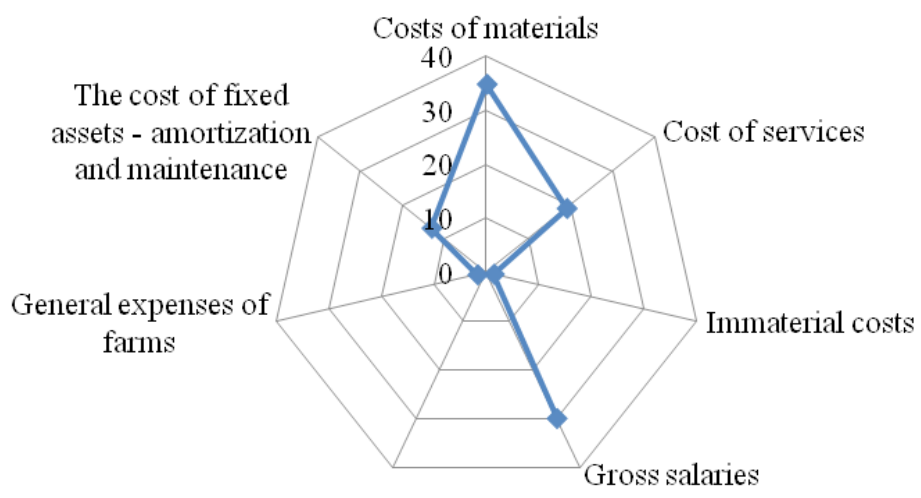

Source: Authors' calculation based on own research

When analyzing the share of costs in total costs in 2014, material costs accounts for $34.79 \%$ followed by the cost of wages with $29.92 \%$. The costs of services were $19.00 \%$ of total cost. Fixed assets accounted for $13.14 \%$, overheads $1.80 \%$, and intangible costs with $1.35 \%$.

The following table shows the calculation of grape production for the period from 2012 to 2014.

Table 11. Economics of grape production for 2012-2014 period

\begin{tabular}{|c|c|c|c|}
\hline Year & Production value (din/ha) & Production costs (din/ha) & Economy coefficient \\
\hline 2012 & $480,410.00$ & $352,253.00$ & 1.36 \\
\hline 2013 & $408,960.00$ & $304,828.00$ & 1.34 \\
\hline 2014 & $519,220.00$ & $334,178.00$ & 1.55 \\
\hline Average & $\mathbf{4 6 9 , 5 3 0 . 0 0}$ & $\mathbf{3 3 0 , 4 2 0 . 0 0}$ & $\mathbf{1 . 4 2}$ \\
\hline
\end{tabular}

Source: Authors' calculation based on own research

Many factors can affect the production economy and some of the most important are: generated volume of production, utilization of existing capacity, applied production technology, organization of the production process, as well as labor productivity, the level of trade funds and more. Average economy coefficient for the analyzed period from 2012 to 2014 was 1.42. In 2014, the economy coefficient was the highest (1.55), which was the result of high-value production - high selling price of $79.88 \mathrm{din} / \mathrm{kg}$. Thus, in 2014 at every 100.00 dinars invested 155.00 dinars was returned. In 2012 the economy coefficient was 1.36 (136 dinars returned for every 100 invested) and in 2013 economy coefficient was 1.34 . 


\section{Conclusion}

Grape production in Serbia takes place at only 25,000 ha with an average annual production of 285,571 t of grapes with year to year variations. In the total production of grapes in Europe, Serbia participates with two per cent and is in 12th place when it comes to production. Despite very favorable conditions for grape growing, production and consumption of grapes and wine in Serbia is not satisfactory. Area under vineyards in Serbia, as well as wine production is significantly decreasing, while individual producers are in a rather unfavorable position.

Wine growing is a highly intensive branch of agriculture, which requires significant investment capital as well as extensive labor work per unit of product. Despite that fact, studies show that Serbia needs less investment per hectare of vineyards than in other EU countries. The poor state of viticulture in Serbia is influenced by old age of vineyards and high vineyard amortization, abandonment of sloping terrain and plants unsuitable for the application of machinery, lack of favorable agricultural loans for establishing new plantations and for the purchase of modern machinery for vineyards, unfavorable varietal structure, and the lack of funds improving viticulture and enology at the individual sector.

Analyzing the grape production for "Nedin" winery in the period from 2012 to 2014 shows that the yields ranged from $6,500 \mathrm{~kg} / \mathrm{ha}$ to $8,000 \mathrm{~kg} / \mathrm{ha}$ with the highest total yield achieved in 2013. The yield varies from year to year as a result of specific conditions in agriculture. In the reporting period an average yield was $7,167 \mathrm{~kg} / \mathrm{ha}$ and the average selling price was 66.54 $\mathrm{din} / \mathrm{kg}$. Average annual value of production was 469,530 dinars $/$ ha, while the average cost of production for the reporting period amounted to $330,420.00 \mathrm{din} / \mathrm{ha}$. Grape is a profitable product, as evidenced by the average income earned per heacter $-139,110$ dinars/ha. The largest annual profit in grape production was achieved in 2014 - 185,042.00 dinars/ha.

Production costs are high, material and labor costs have a dominant share in total costs up to $85 \%$. In the analyzed period, the largest share was accounted by material costs with an average of $34 \%$, most of which is the usage of NPK fertilizer, costs of plant protection (herbicides, insecticides and fungicides) and then other material costs. Average cost of wages was 30\%, due to high labor requirements, especially in matters of pruning and harvesting. In addition to these, costs of services accounted for $19 \%$ of total costs.

Average coefficient of economy for the analyzed period from 2012 to 2014 was 1.42 . In 2014, coefficient of economy was highest (1.55), which was a result of high production value (high selling price of grapes). Bearing in mind the fact that analyzed winery can be used asa representative farm household for South Banat region, results of the analysis can conditionally be applied to the entire region.

\section{References}

1. Crescimanoo, M., Galati, A. (2014): Competitiveness of Italian wines in the international market, Bulgarian Journal of Agricultural Sciences, vol. 20, no. 1, pp. 12-22.

2. Cusmano, L., Morrison, A., Rabellotti, R. (2010): Catching up Trajectories in the Wine Sector: A Comparative Study of Chile, Italy ad South Africa, World Development, vol. 28 , no. 11 , pp. $1588-1602$. 
3. Di Vita, G., D’Amico, M. (2013): Origin designation and profitability for small wine grape growers: evidence from a comparative study, Ekonomika poljoprivrede, vol. 60., no. 1 , pp. 7-24.

4. FAO (2015): FAO Statistical Yearbook 2014, http://www.fao.org/3/a-i3621e.pdf, accession date 21.05.2016.

5. FAO (2009): Grapes, Wine, agribusiness handbook, http://www.fao.org/docrep/012/ al176e/al176e.pdf, accession date 21.05.2016.

6. Hambalkov, M. (2006): The factors of competitiveness and the quantification of their impact on the export efficiency of grape and wine in the Slovac Republic, Agric.Econ. Czech, vol. 52, no. 8, pp. 389-394.

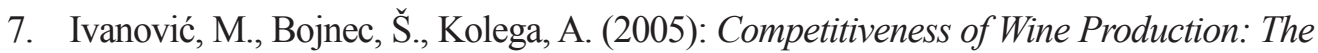
Case of Bosnia and Herzegovina, Die Bodenkulture, vol. 56, no. 4, pp. 219-229.

8. Jakšić, D., Ivanišević, D., Đokić, V., Brbaklija Tepavac, M. (2012): Vinski Atlas, Popis poljoprivrede 2012, Republički zavod za statistiku, Beograd.

9. Marko, J., Jovanović, M, Tica, N. (1998): Kalkulacije u poljoprivredi, Poljoprivredni fakultet, Novi Sad.

10. Milić, D. (2015): Metodi vrednovanja poljoprivrednog zemljišta, doktorska disertacija, Poljoprivredni fakultet, Novi Sad.

11. Overton, J., Murray, W.E. (2016): Investing in place: articulations and congregations of capital in the wine industry, The Geographical Journal, vol. 182, no. 1, pp. 49-58.

12. Petrović, J., Krstić, B., Stanišić, T. (2015): Analiza proizvodnih potencijala i konkurentske pozicije Srbije na međunarodnom tržištu vina, Ekonomika poljoprivrede, vol. 62, no. 3, pp. 813-829.

13. Pike, W., Melewar, T.C. (2006): The demise of independent wine production in France: a marketing challenge?, International Journal of Wine Marketing, vol.18, no. 3, pp. 183-203.

14. Pivac, T., Romelić, J. Košić, K. (2009): Ocena potencijala za razvoj vinskog turizma u Vojvodini, Zbornik radova Geografskog fakulteta, vol. LVII, pp. 215-229.

15. Remaud, H., Couderc, J.P. (2006): Wine Business Practices: A New Versus Old Wine World Perspective, Agribusiness, vol. 22, no. 3, pp. 405-416.

16. Sgroi, F., Trapani, A.M., Testa, R., Tudisca, S. (2014): Strategy to increase the farm competiveness, American Journal of Agricultural and Biological Sciences, vol.9, no. 3, pp. 394-400.

17. Sredojević, Z., Svirčev, B., Peco, E. (2015): Rentabilnost ulaganja u podizanje $i$ eksploataciju zasada vinograda kao izazov za investitore, Agroekonomika, Poljoprivredni fakultet u Novom Sadu, vol.44, no.68, pp. 89-102.

18. Statistical Office of the Republic of Serbia: www.stat.gov.rs, accession date 13.05.2016.

19. Vlahović, B., Potrebić, V., Jeločnik, M. (2012): Preferences of wine consumers on Serbian market, Economics of Agriculture, vol. 59, no. 1, pp. 37-49.

20. Winery Nedin: www.vinarijanedin.rs, accession date 17.05.2016.

21. Wittwer, G., Berger, N., Anderson, K. (2003): A model of the world's wine markets, Economic Modelling, Elsevier, no.20, pp.487-506. 


\title{
EKONOMSKA OBELEŽJA PROIZVODNJE GROŽĐA U JUŽNO-BANATSKOM OKRUGU $^{8}$
}

\author{
Dragan Milić ${ }^{9}$, Danica Glavaš-Trbičc ${ }^{10}$, Mirela Tomaš-Simin ${ }^{11}$, Dejan Jankovićc ${ }^{12}$, \\ Vladislav Zekić13
}

\begin{abstract}
Rezime
Proizvodnja vina u Srbiji ima veoma dugu tradiciju. Srbija ima velike prirodne potencijale za proizvodnju grožđa $i$ vina, ali su oni na niskom nivou iskorišćenosti. Vinogradarska proizvodnja u Srbiji odvija se na svega 25,000 ha sa prosečnom godišnjom proizvodnjom grožđa od 285,571 t sa varijacijama po godinama, ali su površine pod vinogradima, kao i sama proizvodnja vina, u značajnom opadanju, dok su glavni nosioci proizvodnje mala porodična domaćinstva, odnosno individualni proizvođači. Predmet istraživanja u ovom radu su ekonomska obeležja proizvodnje vinove loze, odnosno proizvodnja grožđa u Južnobanatskom rejonu, odnosno Vršačkom vinogorju, koje zauzima 81,2\% od ukupnog vinogorja u ovom delu Vojvodine.
\end{abstract}

Ključne reči: proizvodnja grožđa, vino, vinogradarstvo, ekonomska obeležja, Republika Srbija.

8 Rad je deo istraživanja u okviru projekta broj III 46006 pod nazivom, Održiva poljoprivreda i ruralni razvoj u funkciji ostvarivanja strateških ciljeva Republike Srbije u okviru Dunavskog regiona“ i ON 179028 „Ruralno tržište rada i ruralna ekonomija Srbije - diverzifikacija dohotka i smanjenje siromaštva“" koji finansiraju Ministarstvo prosvete, nauke i tehnološkog razvoja Republike Srbije. Projektni period 2011-2016.godine.

9 Docent, dr Dragan Milić, Univerzitet u Novom Sadu, Poljoprivredni fakultet, Trg Dositeja Obradovića br. 8, 21000 Novi Sad, Srbija, Telefon: +381 63 560135, E-mail: draganzavod@ gmail.com

10 Asistent, MSc. Danica Glavaš - Trbić, Univerzitet u Novom Sadu, Poljoprivredni fakultet, Trg Dositeja Obradovića br. 8, 21000 Novi Sad, Srbija, Telefon: +381 63 8878701, E-mail: danicagt@polj.uns.ac.rs

11 Asistent, MSc. Mirela Tomaš - Simin, Univerzitet u Novom Sadu, Poljoprivredni fakultet, Trg Dositeja Obradovića br. 8, 21000 Novi Sad, Srbija, Telefon: +381 62 240123, E-mail: mirelat@polj.uns.ac.rs

12 Docent, dr Dejan Janković, Univerzitet u Novom Sadu, Poljoprivredni fakultet, Trg Dositeja Obradovića br. 8, 21000 Novi Sad, Srbija, Telefon: +381 63 574750, E-mail: jankovic@polj. uns.ac.rs Koresponding autor.

13 Redovni profesor, dr Vladislav Zekić, Univerzitet u Novom Sadu, Poljoprivredni fakultet, Trg Dositeja Obradovića br. 8, 21000 Novi Sad, Srbija, Telefon: +381 63 560214, E-mail: vladislav.zekic@gmail.com

EP 2016 (63) 4 (1187-1203) 